\title{
ANALYSIS OF CONSIDERATIONS IN CSR ASPECT \\ TOWARDS INCENTIVE TAX OF PT MASPION III IN SIDOARJO JAWA TIMUR (An Empirical Study of CSR at PT. Maspion III Sidoarjo)
}

\author{
Bayu Adi ${ }^{1)}$, Moh Afrizal Miradji ${ }^{2)}$ \\ Accounting Study Program of Econmics Faculty \\ University of PGRI Adi Buana Surabaya \\ Email: afrizal@unipasby.ac.id
}

\begin{abstract}
CSR has developed into part of the company's business strategy, mainly related to the functions of marketing, public relations, and investment-decision making (Subagyo, 2018). PT. Maspion III in CSR activities has developed into a part of the company's business strategy. in the taxation aspect at PT. Maspion III is one of the important factors that is considered by an organization in designing its CSR program to produce CSR programs that can add business value as well as tax favorable. Whereas on the other hand Maspion III spent funds for its CSR program based on Act Number 36 of 2008 which has regulated the treatment of Income Taxes on expenses or costs incurred in the context of Corporate Social Responsibility (CSR). Provisions regarding this matter are regulated in Article 6 paragraph (1) letters $\mathrm{I}, \mathrm{j}, \mathrm{k}, \mathrm{l}$, and $\mathrm{m}$, in which it is stressed that the amount of taxable income for permanent establishment of permanent establishment), which in fact is reduced in Article 1 PP 93 of the year 2010, for the expenditure of Corporate Social Responsibility (CSR) which can be deducted by a certain\%. While for PT. Maspion III for its CSR Program exceeds the provisions of 5\%. Therefore, to be able to produce CSR programs that can produce business value programs as well as tax favorable, it is better if the taxpayer considers the taxation aspects when designing his CSR program.

Keywords: $\quad$ CSR Aspect Considerations, CSR Tax Incentives, CSR draft, Law
\end{abstract}

\section{Introduction}

Kartini (2009) suggested that the concept is the term corporate social responsibility (CSR) as the emergence of reactions in global corporations in the era of 20 years to 30 years. In developments in the industrial era, public awareness about the role of corporations can increase growth in the economy and create many jobs, plus applications in technology that are highly developed in this millennial era. On the other hand, there are many criticisms of corporations due to adverse impacts on both social and environmental impacts such as pollution, depletion of natural resources, waste, low product quality and workers' rights in terms of this often neglected, as well as the impacts on the company. large scale of concern in the community which in essence the company must not ignore the complaints of the community.

In Surabaya is a well-known city. As an Industrial and Trade City, which must comply with Industry regulations, Taxation Regulations by making periodic Financial Statements in accordance with Indonesian GAAP and can prove the fairness of the financial statements so that the financial reports reported in the tax entity are reasonable and reflect the circumstances the real company but in reality the company is also required to face a great responsibility for the impact of its business activities on society here the company is required to be more transparent and accountable to all stakeholders - not only for creditors and shareholders but also the public. 
Nobel Prize-winning economist Milton Friedman (2008) argues that in social responsibility carried by corporations, don't just maximize profits, and can no longer be universally accepted. The following excerpts Milton "Few trends could be so thoroughly undermined the very foundations of our free society as the acceptance by corporate officials of a social responsibility other than to make as much money for their stockholders as possible."

This shows about the awareness of the executives of the company. In another case, according to Yusuf (2007), it was stated that in addition to creating maximum economic benefits, corporations must be obliged to help the community / respond to society. On the other hand the same thing According to Subagio (2018) explains that the companies that have the best rank must interact socially between the community and corporations in this case such as giving donations, empowering communities around the company, for example about environmental preservation, empowering the surrounding population in economic matters, and also the company is required to have performance in financial statements that are reasonable and accountable, with the size intended in the sales-to assets ratio, return on equity, earnings-to-asset growth, return on investment, return on assets,. So with the above mentioned, the writer is interested in proving that whether CSR Capital socio responsibility is really done considering CSR is so important, the writer is interested in taking the example of a large company, PT. Maspion is engaged in the field of Electronics and others, considering that PT Maspion is a large PT and its company is not only domestically, but even abroad, which in fact is a Pioneer company in the electronics and cooking utensils sector in Indonesia, given the enormous size of the company in terms of this then limits itself to only researching about CSR in Maspion III which is one of the PT Maspion Production Companies located in Sidoarjo, East Java. And in this case also remember that PT Maspion often provides scholarships to students with pretensions as a form of CSR programs.

\section{Theoretical Framework}

Mas Ahmad (2009) stated in his literature CSR as "a mechanism for organizations to voluntarily integrate social and interactions with their stakeholders, which is over and above the organization's legal responsibilities". It means that the CSR program is also an application of responsible business practices. It means that CSR programs are implementation programs of sustainable development principles, which require companies not only to consider economic factors such as profits and dividends, but social and environmental conditions to maintain the trust and loyalty of their stakeholders. This is of course in order to achieve sustainable financial performance and relevant tax regulations that support which of course is sustainable for the Economy. Pursuant to Article 74 of the Law downgraded in PP Number 40 of 2007 concerning Limited Liability Companies (PT), namely the obligation of the government to control CSR programs for large or multinational companies for their business activities which memorandum bene encourages companies to implement CSR Programs and of course Regulations on taxation are obliged to interpret the CSR Program.

\section{Treatment in Tax Incentives for Overseas CSR Activities}

Ismail (2009) suggests using the same incentives as tax exemption, tax deduction, and tax credittax incentive policies for CSR programs are in fact applied at different levels in each country. In a similar according to Fajar (2010) stated that developing countries such as India, Bangladesh, and the Philippines, providing tax exemption and tax deduction policies for CSR activities are considered very relevant to the economic empowerment of the people and in developed countries such as Australia, China, America, Africa South, the application of tax exemption and tax 
Vol-3, Issue-4, 2019 (IJEBAR)

E-ISSN: 2614-1280 P-ISSN 2622-4771

https://jurnal.stie-aas.ac.id/index.php/IJEBAR

deduction in activities for CSR is aimed at creating investment at least for a part that is conducive to both domestic and foreign companies. The company always has a tendency to see a constant relationship between inventory levels and services provided to customers. Afrizal (2014).

\section{CSR in Indonesian Taxation}

\section{Tax incentives for CSR}

Philanthropy or Tax Incentives According to Mukti (2010) stated that based on tax regulations in force in developing countries. Following are the incentive programs used are as follows:

\section{a. Tax Exemption}

CSR embraces Tax Exemption which means giving a sense of fairness to the process of certain economic activities towards the community around the company.

b. Tax Deduction / Tax Allowance / Tax Relief

CSR adheres to the policy based on Php Kp's CSR activities, so that the range of tax rates will be smaller.

\section{c. Tax Credit}

CSR embraces as a deduction from the tax payable which will reduce the amount of tax burden in real terms for the deduction of the Company. In practice, the three forms of tax incentives for each State differ according to the constitutional area and the political decision of the government in each country or within the territory of the country but also in the provinces of each country. In the realm of taxation law according to Primandita (2010) states that the Income Tax Law Number 36 Year 2008 in this case explains in paragraph (1) that for the letter $d$ in number $4 a$ down Article 3 states that for Income Tax Objects there is income in it there is a profit because there are sales in other cases there is also the transfer of assets in the form of grants, assistance, or donations, except those given to blood relatives in the lineage of semenda and straight lines examples in the fields of: religious business entities, educational business entities, social organizations and micro and small businesses. Then it is explained again in Article 4 paragraph (3) letter a, that the Income Tax Law also regulates other CSR activities that are exempted from the Income Tax object. Giving in zakat may be received by the amil zakat body authorized by the government or that has been accredited is mandatory for adherents of the religion formed or authorized by the government and received by the recipient with reference to government regulations. In addition, in Article 4 paragraph (3) letter $\mathrm{k}$ of the Income Tax Law, it is regulated that the income received or obtained by a venture capital company in the form of profit from a business partner that is established and runs a business or activity in Indonesia, is excluded from the income tax object. With a note, the business partner entity is a micro, small, medium-sized company, or which carries out activities in business sectors regulated by or based on PMK and its shares are not traded on the stock exchange in Indonesia. Not only until it is discussed in Article 4 paragraph (3) letters 1, m, and the Income Tax Law also governs the exemption of income tax on CSR activities. As with scholarships that meet certain requirements, the remaining is more received or obtained by non-profit (Non-Profit) bodies or institutions engaged in education and / or research and development fields that have been registered with the agencies that field them - which are reinvested in the form of educational facilities and infrastructure and / or research and development for a maximum period of 4 (four) years. In addition, the government provides a policy for tax incentives which is a CSR activity in the form of a deduction or tax deduction. As regulated in Article 
6 paragraph (1) of the Income Tax Law, there are a number of costs associated with CSR activities that are allowed as deductible expense:

- Industrial waste treatment or benefit the surrounding community;

- Scholarships and training in the world of Education;

- National disaster management in the form of donations

- Research and development for accredited institutions

- Development of social infrastructure

- Educational facilities

- Sports coaching

That all of these are appointed by the government, which here the government is the regulatory body between the companies which is revealed in government regulations. Recognition Based on Government Regulations CSR Costs with Tax Government Regulations regarding the Form of CSR. Based on PP 93 of 2010 Article 1 which is an elaboration of Article 36 of Law, that the expenditure of Corporate Social Responsibility (CSR) will get a direct deduction (deductive cost) of a certain amount and a brutal income for accredited recipient institutions. which consists of the following that can be administered:

a. In National Disaster Management, victims of natural disasters that are authorized nationally by the central government and delivered directly through accredited government-appointed body means that they receive direct or direct government recognition.

b. In research in development, research and development carried out in the territory of the Republic of Indonesia which is delivered through scientific research and development institutions that use methods that are required by the example of tertiary institutions; c. In facilities in education, educational facilities delivered through educational institutions that include national culture such as scouting, sports to institutions that have been accredited by the government;

c. In Coaching in sports, Fostering, developing and coordinating branches / types of sports fields through sports coaching institutions; namely in the form of Competition e. In Infrastructure in social activities are costs incurred by companies to build facilities and infrastructure of public interest given to non-profit organizations that have been accredited by the government.

Requirements to be deducted

CSR Expenditures According to Subagio (2018) in the form of costs in the form as mentioned above can be deducted from gross income provided that:

1. Intended to an accredited recipient

2. da Taxpayer (WP) who has a net fiscal income for the Tax Year in the period of the previous year;

3. Donations for costs those are not detrimental

4. Donation recipient institutions must have a TIN

CSR recipients are not parties who have a special relationship.

\section{Research methods}

Types of research

In researching in this study, the data used and analyzed using descriptive quantitative techniques means using a measure based on the \% CSR CSR determined 
Peer Reviewed - International Journal

Vol-3, Issue-4, 2019 (IJEBAR)

E-ISSN: 2614-1280 P-ISSN 2622-4771

https://jurnal.stie-aas.ac.id/index.php/IJEBAR

\section{Data Collection Instruments}

Data collection

This research uses the existing method in Sugiyono (2015: 72) which uses the technique of collecting data documentation, interviews, fiscal reports in 2018 taken from the Bayu And Partners Tax Consultants.

\section{Data Collection Procedure}

Data collection procedure is using secondary data taken from PT Maspion III's Financial Statements.

\section{Population and Sample}

In this study, the population is the statement of the PT. Maspion III Period 2018 before the publication of the Annual financial statements

\section{Research Variables and Operational Definition Variables}

In this study, the Independent Variables, namely: Percentage of Corporate Income Tax

The researcher uses the $\%$ Count as follows:

Based on Law No. 36/2008, it regulates the treatment of income tax on expenses or costs incurred in the context of Corporate Social Responsibility (CSR). Provisions regarding this matter are regulated in Article 6 paragraph (1) letters $I, j, k, 1$, and $\mathrm{m}$, in which it is stressed that the amount of taxable income for domestic taxpayers and permanent permanent establishment), which in fact is reduced in Article 1 PP 93 of 2010, forms of Corporate Social Responsibility (CSR) expenditure which can be deducted to a certain amount.

\section{Analysis and Discussion}

\section{Analysis}

By using a quantitative descriptive test, the percentage results obtained are permitted in CSR regulations according to tax

\section{Discussion}

PT. Maspion III in CSR activities has developed into a part of the company's business strategy, especially in carrying out the functions of marketing, public relations and investment-decision making. in the taxation aspect at PT. Maspion III is one of the important factors considered by the organization in designing its CSR program to produce CSR programs that can add business value as well as tax favorable. Furthermore, costs associated with CSR activities can be deducted (deductible expense) when calculating the tax base. Whereas on the other hand Maspion III spent funds for its CSR program based on Act Number 36 of 2008 which has regulated the treatment of Income Taxes on expenses or expenses incurred in the context of Corporate Social Responsibility (CSR). Provisions regarding this matter are regulated in Article 6 paragraph (1) letters I, j, k, 1, and m, in which it is stressed that the amount of taxable income for domestic taxpayers and permanent permanent establishment), which in fact is reduced in Article 1 PP 93 of 2010, forms of Corporate Social Responsibility (CSR) expenditure which can be deducted to a certain amount.

- Waste treatment costs; Rp. 10,000,000,000

- Scholarship, apprenticeship and training costs; Rp. 5,000,000,000

- National disaster relief contribution Rp. 9,000,000,000 
- $\quad$ Research and development contributions Rp. 10,000,000,000

- Social infrastructure development costs Rp. 10,000,000,000

- Donated educational facilities Rp. 9,000,000,000

- Contribution in the context of sports coaching Rp. 8,000,000,000 While PT Maspion III's Fiscal Net Income is 300,000,000,000 minus 61,000,000,000, meaning that the total amount is $239,000,000,000$, whereas the specified conditions are Rp. 15,000,000,000 and 61,000,000,000 are reduced by 15,000,000,000 which means $46,000,000,000$ this shows that PT Maspion III exceeds the specified $5 \%$ or about $20 \%$

\section{Conclusions and suggestions \\ Conclusions}

Tax deduction which is a form of tax incentive must consider performance. The incentive system for high performers must be balanced with the incentive system for those who have low performance for the sake of creating justice. PT Maspion III shows that CSR provided to the community is very adequate and even exceeds the standards prevailing in countries such as America means the support of its people. To be able to produce CSR programs that produce business value programs as well as tax favorable, it is better if taxpayers consider the taxation aspects when designing their CSR programs.

\section{Suggestion}

Charges allocated from net income after tax by forming a non-profit CSR institution channeling revolving funds to the community productively create an accountable and transparent CSR implementation system.

\section{References}

Daniri, Mas Ahmad 2008, Standariasi Tanggung Jawab Sosial Perusahaan. Kementrian Badan Usaha Milik negara Edisi Ke Empat, cetakan Pertama Penerbit STIM YKPN

Fajar, Mukti 2013, Tanggung Jawab social Perusahaan Edisi Pertama Pustaka Pelajar : Yogyakarta

Kartini, Dwi, 2009, Corporate Social responsibility Transformasi konsep Sustainbility management dan Implementasi di Indonesia, Penerbit Alfabeta :Bandung.

Milton Friedman (2008) https://spectrummagazine.org/article/column/2008/12/30/miltonfriedman-master-disaster (diunduh 1/9/2019)

Moh Afrizal Miradji ,2014 Analisis Supplay Chain Management pada PT Monier di Sidoarjo, Balance Management and Accounting jurnal Volume X/No. 19/Juli 2014, Hal 63-82 , Faculty of Economic Muhamadiyah Surabaya

Primandita Fitriandi, Dkk, 2010, Kompilasi Undang-undang Perpajakan Penerbit : Salemba empat, Jakarta

PP Nomor 40 Tahun 2007 http://ditjenpp.kemenkumham.go.id/arsip/ln/2007/pp40-2007.pdf (diunduh 1/9/2019)

PPh Nomor 36 Tahun 2008 http://www.pajak.net/blog/peraturan/UU-36-2008.pdf (diunduh $1 / 9 / 2019)$

PP 93 Tahun 2010 https://luk.staff.ugm.ac.id/atur/PP93-2010PenguranganPajak.pdf (diunduh $1 / 9 / 2019)$

Subagio, 2018, Majalah Indonesia Tax Review Vol III/ Edisi 19/2010. Penerbit Associate Tax Center (UKI)

Solihin, Ismail, 2009, Corporate Social responsibility, Edisi kedua, Salemba Empat: Jakarta 
International Journal of Economics, Business and Accounting Research (IJEBAR)

Peer Reviewed - International Journal

Vol-3, Issue-4, 2019 (IJEBAR)

E-ISSN: 2614-1280 P-ISSN 2622-4771

https://jurnal.stie-aas.ac.id/index.php/IJEBAR

Sugiyono, 2015, Metode Penelitian Kuantitatif, Kualitatif, Dan R\&D, Bandung: Alfabeta.

Wibisono, Yusuf 2007, Membedah Konsep Aplikasi CSR. Edisi Pertama Fascho : Gresik 